\title{
Impacts of sewage irrigation on soil properties of a farmland in China: A review
} Impactos del riego con aguas cloacales en las propiedades del suelo de una granja en China: Una revisión

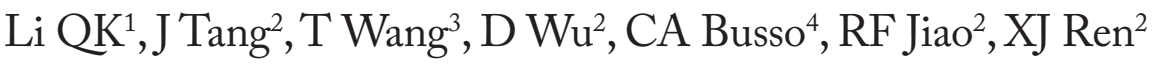

\begin{abstract}
Fresh water is a valuable nonrenewable resource and plays an important role in maintaining economic and social development. Considering its large population and consumption potential, water resource deficits will certainly not allow a sustainable development of basic industries in China in the near future. Application of sewage irrigation, to some extent, was regarded as an alternative way to solve the problem of agricultural water shortage in some areas (such as North China). However, accompanied with an extensive implementation of sewage irrigation, some problems with sewage irrigation became gradually obvious in agriculture, especially those related with pollution and destruction of farmlands. In this paper, the effects of sewage irrigation on soil physical (soil bulk density, soil resistance to penetration and field capacity), chemical ( $\mathrm{pH}$, soil organic matter, nitrogen, phosphorus, potassium, heavy metal and organic pollutants) and biological characteristics (soil microorganisms and enzyme activities) were systematically reviewed on farmlands in China, based on the current utilization status of China's farmland sewage irrigation. Some feasible suggestions were put forward to the development prospects in the future. This review will be beneficial for promoting a healthy development of sewage irrigation and providing a theoretical support for reclamation and a high efficiency use of effluents in China.
\end{abstract}

Keywords: Wastewater irrigation; Soil characteristics; Agriculture; Pollution; China.
Resumen. El agua limpia es un recurso valioso y juega un rol importante en mantener los desarrollos económico y social. La limitación de recursos hídricos ciertamente no permitirá un desarrollo sostenible de las industrias básicas en China en un futuro cercano, considerando su gran población y potencial de consumo. La aplicación de aguas cloacales, hasta cierto punto, se observó como un camino alternativo para resolver el problema de la escasez de agua en agricultura en algunas áreas (tales como en el Norte de China). Sin embargo, acompañado con una implementación extensiva de riego con aguas cloacales, algunos problemas se hicieron obvios, especialmente aquellos relacionados con la contaminación y destrucción de granjas. En este manuscrito se revisaron los efectos del riego con aguas cloacales en granjas en China sobre algunas características físicas (densidad aparente del suelo, resistencia del suelo a la penetración y capacidad de campo), químicas ( $\mathrm{pH}$, materia orgánica del suelo, nitrógeno, fósforo, potasio, metales pesados y contaminantes orgánicos) y biológicas de suelo (microorganismos del suelo, y actividad enzimática). Esto se basó en el grado actual de utilización del riego con aguas cloacales de las granjas de China. Se propusieron algunas sugerencias posibles con respecto a las perspectivas de desarrollo en el futuro. Esta revisión será benéfica para promover un desarrollo saludable del riego con aguas cloacales y proveer un apoyo teórico para el reclamo y un gran uso eficiente de los efluentes en China.

Palabras clave: Riego con aguas de desperdicio; Características del suelo; Agricultura; Contaminación; China.

\footnotetext{
${ }^{1}$ Yellow River Institute of Hydraulic Research, Yellow River Conservancy Commission, Zhengzhou, 450003, China.

${ }^{2}$ School of Resource and Environment, Henan Institute of Science and Technology, Xinxiang, 453003, China.

${ }^{3}$ Third Institute of Geo-exploration Institute, Henan Bureau of Geo-Exploration \& Mineral Development, Zhengzhou, 451464, China.

${ }^{4}$ Departamento de Agronomía-CERZOS (CONICET: Consejo Nacional de Investigaciones Científicas y Técnicas de la República Argentina), Universidad Nacional del Sur, San Andrés 800, 8000 Bahía Blanca, Argentina.

Address correspondence to: Dafu Wu, e-mail: uau9393@163.com

Received 10.II.2018. Accepted 4.III.2018.
} 


\section{INTRODUCTION}

Water is not only a valuable natural resource that maintains people's survival and development, but also constitutes the main constituent element of the environment (Bouwer, 1994; Molles, 2008; Piao et al., 2010; Gu et al., 2017). China is rich in the volume of total water resources. In this country, the total amount of fresh water resources could reach $2.81 \times 10^{12} \mathrm{~m}^{3}$, which account for about $6 \%$ of the global water resources (Zhang \& Wang, 2007; Thomas, 2008). However, the per-capita water resource volume is relatively limited, (i.e., $2.3 \times 10^{3} \mathrm{~m}^{3}$ ), considering the large population of China. It only represents $25 \%$ of the world average level, becoming thus one of the poorest countries of water resources per capita (Karr, 1991; Wang et al., 2008; Fatta-Kassinos et al., 2011). Even worse, the regional water resource characteristics and seasonal distribution in China constrain the sustainable development of economic and social developments in water shortage areas (Piao et al., 2010).

As a vast agricultural country, extensive quantities of water are consumed in China's agricultural production. Irrigation water accounts for more than $70 \%$ of the total water consumption (Yang, 2000; Qadir et al., 2010; Shi et al., 2014). At present, about $50 \%$ of the total cultivated land could be irrigated. Non-irrigated lands currently produce about $75 \%$ of the nation grain output, more than $80 \%$ of cotton, and more than $90 \%$ of vegetables (Jin \& Young, 2001; Liu \& Xu, 2002; Zeng \& Zhu, 2004). With the rapid development of the national economy and the continuous improvement of people's quality of life, industrial and domestic water consumption increase continuously. This reduces the water available with agricultural purposes. In addition, irrigation water is not guaranteed, and water shortage is becoming increasingly serious as a result (Bouwer, 1994; Brown \& Halweil, 1998; Vörösmarty et al., 2000). In China, agricultural water shortage per year is about $3.0 \times 10^{10} \mathrm{~m}^{3}$, determining a reduction in grain yield of $2.5-4.0 \times 10^{10} \mathrm{~kg}$ (Brown, 1995; Zhou, 2002; Wang et al., 2010). At the same time, the total amount of water discharged as waste from industrial and urban areas is increasing. This waste water is relatively concentrated, and it is not affected neither by seasonal changes nor floods. Most of the untreated waste water is poured directly into rivers, lakes and reservoirs, which determines a potential threat to the ecological environment (Rusan et al., 2007; Qadir et al., 2010).

Water resource depletion in agriculture results in that large amounts of sewage are used for irrigation on a global scale. Nearly $2.0 \times 10^{6} \mathrm{~km}^{2}$, involving 50 countries, are irrigated by sewage (Wallach et al., 2005; Qadir et al., 2007; Abaidoo et al., 2010). There were $4.3 \times 10^{5} \mathrm{~km}^{2}$ of irrigated farmland worldwide at the end of 2009 . This accounted for $7.3 \%$ of the total irrigated area in China (Fang, 2011). Sewage irrigation shows a rising trend, especially in northern China, since it is the main area of water shortage. Application of sewage solves the problem of water shortage for agricultural irrigation in this area (Rusan et al., 2007; Qadir et al., 2010). There are reports that sewage irrigation is currently focused on the Haihe, Liaohe, Yellow and Huaihe river basins, which represent about $85 \%$ of the area irrigated by sewage (Liu \& Xu, 2002). In developed countries, the techniques of sewage treatment and reutilization have improve enough as to achieve the dual purposes of water conservation and pollution control (Angelakis et al., 1999; Wallach et al., 2005; Fatta-Kassinos et al., 2011). However, the sewage treatment techniques have lag behind in China and water quality will not reach good enough standards for a long time. Even worse, management of sewage irrigation and monitoring systems have not been appropriate (Fang, 2011). More attention was paid to determine it longterm sewage irrigation either affected or not the soil properties of farmlands in China (Tang et al., 2004; Liu et al., 2005; Khan et al., 2008; Meng et al., 2016).

This paper reviews the effects of sewage irrigation on soil physical, chemical and biological characteristics of farmlands in China, including suggestions for the development of perspectives in the near future. This specific objective seek to (1) promote the sustainable development of sewage irrigation in China, and (2) provide a theoretical support for the high efficiency of sewage in reclamation programs.

\section{History of sewage irrigation}

Commonly, production is not the result of using domestic sewage directly. Engineering is needed to obtain effluents after applying appropriate treatments that will meet the irrigation quality requirements for (1) irrigating farmlands and grassland landscapes, and (2) contributing to the groundwater recharge, solving the lack of water resources and achieving eventually sewage reclamation (Xia \& Wang, 2001; Liu \& Xu, 2002; Qadir et al., 2010). Many developed countries in the world have realized quite early on the strategic significance of sewage reutilization. Western European countries began to use sewage to irrigate farmlands since the middle of the 16th century. Germany is considered to have the world's largest and oldest sewage irrigation sites. In this country approximately $10^{2} \mathrm{~km}^{2}$ of marginal and low-productivity land have been irrigated by sewage since 1928 (Hass et al., 2012; Lottermoser, 2012). The first country which made large-scale utilization of sewage irrigation was the U.S.A, where a suitable water purification system was assembled in 1920; some research and intensive utilization of sewage irrigation was conducted in this country (Chen et al., 2000; Sabol et al., 1987). To date, its wastewater treatment technology and application scope keep a leading role in the world. Japan began recycling sewage and implemented rural sewage treatment projects since the 1960's. Approximately in the year 2000, small sewage treatment plants were implemented on a national scale, depending on small sewage treatment systems for agricultural irrigation in the 1970's (Francks, 1979; Morishita, 1988). As one of the 
most severely water-deficient countries in the world, Israel has established a comprehensive sewage system and sewage treatment projects in all of its cities and settlements (Heukelekian, 1957; Chen \& Zhou, 2001; Jueschke et al., 2008). Almost all of its wastewater was effectively processed and utilized (Wallach et al., 2005). More than 57\% of the sewage after purification has been used for irrigation in agriculture, gardens and lawns. This accounts for about $20 \%$ of the total irrigation water. This made Israel a very efficient water utilization country (Chen \& Zhou, 2001). Other countries, such as Tunisia, India, Jordan and Mexico, have also conducted relevant research on wastewater irrigation, and already accumulated a wealth of experience (Siebe \& Fischer, 1996; Bouri et al., 2008; Abu-Sharar et al., 2010; Singh et al., 2012).

For sewage irrigation safety, different countries and international organizations have created a set of standards in practice (EPA, 1992; FAO, 1985). In 1973, the World Health Organization (WHO) published health guidelines of wastewater recycling for farmland irrigation and aquaculture. These guidelines claimed that sewage for farmland should be treated strictly. As a result, guidelines referring to some indexes were adjusted, and new guidelines were published in 1989. However, those standards were too rigid and of little practical value when they were made popular. The result was that most countries and regions did not follow them. The Food and Agriculture Organization (FAO) also issued two technical reports about wastewater treatment and irrigation recycling, and control of effluent quality; this was because of the current sewage irrigation utilization worldwide (Pescod, 1992; Wescott, 1997). The water quality requirements and sewage treatment methods for agricultural irrigation were also discussed, and some guidance of sewage irrigation were proposed in view of the development levels of various countries.

\section{Application of sewage irrigation in China}

Compared with some developed countries, the source of sewage irrigation comes mainly from untreated or raw domestic and industrial wastewaters (Pedrero et al., 2010). There has been a long history on peasants in using human wastes to fertilize farmlands on many parts of China. The development of sewage irrigation emerged later given a level of economic development and urbanization for the country (Liu et al., 2005; Zeng et al., 2007; Zhang, 2014). There are three periods to take into account in accordance with the developmental scale and stage. The first period is classified as spontaneous irrigation because of using sewage effluents (Liu \&Xu, 2002). Peasants who lived in the suburban of Beijing began to mix domestic and industrial effluents for farmland irrigation in the 1940's. But the emission loads of sewage were relatively limited to a small scale: the national sewage irrigation area was just only $1.16 \times 10^{2} \mathrm{~km}^{2}$ (Li \& Luo, 1995; Zhang, 2014). The second period is regarded as a preliminary stage of development from 1957 to 1972. In 1957, the Chinese government developed sewage irrigation projects. At this time, the Ministry of Construction Engineering, Agriculture and Health expanded sewage irrigation to national scientific research projects, prompting its preliminary development and forming a certain scale. The first pilot scheme for sanitary management of sewage irrigation came out four years later (Zhang, 2014). In the 1970's, the implementation of reformation and opening policies, and household contract responsibility systems accelerated the development of urban and rural enterprises. Sewage irrigation entered a fast-developing period, and faced unprecedented historical challenges. Firstly, some problems of water resource shortage were gradually highlighted, and sewage irrigation areas increased dramatically as a result. More than $3.62 \times 10^{4} \mathrm{~km}^{2}$ of farmlands in China were irrigated using sewage effluents at the end of the $20^{\text {th }}$ century (Wang \& Lin, 2003). Although the Chinese government revised a series of irrigation water quality standards, which were applied to surface water, groundwater, aquaculture-treated wastewater, and farmland irrigation, water came from effluents that were mainly agricultural products such as raw materials in 1979, 1985 and 1992. Some standards for controlling organic pollutants were also increased, and they became national mandatory standards (Shi et al., 2008). However, just like many laws and regulations in China, these standards only existed in name in practice (Jin \& Young, 2001, Fang, 2011). With the rapid development of the national economy, the industrial and domestic sewage water quality changed dramatically, and toxic and harmful organic pollutants increased continuously (Weber et al., 2006). Some current indicators of water quality standards could not adapt to the requirements for sewage irrigation. As a result the Chinese government came to realize about the hazards of sewage irrigation for agricultural production (Liu et al., 2005; Shi et al., 2006). A file of work arrangement on soil environmental protection and comprehensive adjustment for the near future was finally issued by the General Office of the State Council on January 28,2013. This was the first time an authority explicitly prohibited the use of wastewater containing heavy metals, refractory organic pollutants and sludge, dredging of sediments, untested tailings, or safety disposal for agricultural production. However, the relevant standards or guidelines of wastewater irrigation including the new conditions have been delayed due to various economic benefits.

\section{Influence of sewage irrigation on soil properties}

Soil is not only the base for supporting plant both growth and breeding, but also the foundation of human agricultural production (Killham, 1994; Molles, 2008). All kinds of human agricultural production activities are mainly carried out in the soil, and abundant agricultural products are acquired directly or indirectly from it. Soil is located in the interface of the atmosphere, lithosphere, hydrosphere, and biosphere, participating in a variety of processes involving physics, chemistry and biochemistry, and becoming the crucial location for nutrient cycling and energy flux (Killham, 1994; Huang, 2000). Its 
existence provides a relatively stable survival and procreation environment for aboveground vegetation and underground microorganisms (Li et al., 2000).

In China, untreated sewage is often used directly for farmland irrigation in agricultural production. For substances dissolved in sewage, there are mainly four approaches of transference after migrating into the soil (Wang \& Lin, 2003; Zeng \& Zhu, 2004). Some of them would gradually be reduced by the soil self-purification; others would be adsorbed and retained in the soil layer; some of them could be absorbed by the crops, and the rest would enter aquifers following water infiltration (Qadir et al., 2010; Keesstra et al., 2012). Soil, to some extent, has the capacity to clear and degrade pollutants via metabolism (e.g., via microorganisms), increasing some nutrient content and fertility in the soil. However, long-term irrigation using sewage that does not conform water quality standards, allows infiltration of organic pollutants, heavy metals, solid suspended particles and bacteria microbes into the soil (Rusan et al., 2007; Zeng et al., 2007; Fatta-Kassinos et al., 2011; Meng et al., 2016). These contents, nevertheless, might be beyond the soil capacity of self-purification, causing serious soil pollution and giving rise to some changes of soil physical, chemical and biological characteristics.

Effects on soil physical characteristics. Long-term sewage irrigation damages the balance of nature, causing ecological deterioration on farmlands (Wiel-Shafran et al., 2006). Its most direct effect on soil physical properties includes structural damage, functional disturbance and soil hardening (Wang \& Lin, 2003). Soil bulk density is one of the important indicators for measuring the effects on soil physical properties. It reflects the degree of soil compaction to a certain extent, which has a great influence on soil aeration, soil water holding and absorption capacities, infiltration, soil erosion resistance ability and solute migration (Huang, 2000). The porosity of soil depends on changes in soil bulk density (Neves et al., 2003). A study on the consecutive irrigation of calcareous soil in China showed that long-term sewage irrigation changed soil structure significantly. Soil porosity and bulk density had a close correlation with sewage irrigation time. As time increased from sewage irrigation, the soil porosity decreased while the soil bulk density increased (Li, 2001). Furthermore, irrigation by effluents containing high salinity increased soil salinization and enhanced both total and sodium alkalinity in the soil. This caused soil hardening and a decrease in soil permeability ( $\mathrm{Li}$ et al., 2003; $\mathrm{Li}$ et al., 2006). There are also reports that the organic matter, microorganisms, fiber and sediments from sewage deposited in the soil surface exerted a negative impact on soil physical traits, which resulted in a degradation of soil permeability and an increased soil compaction (Siebe \& Fischer, 1996).

The most conspicuous result of soil hardening is its resistance to penetration, which is an important index for measuring the resistance to crop root elongation (Barber, 1994; Mullins et al., 1994). Generally, it is related to soil aggregate characteristics and soil particular spatial arrangement (Ahmed et al., 1987; Franzluebbers et al., 2000). A study in the Weihe River irrigation area by $\mathrm{Hu}$ (2010) found that the topsoil of a farmland irrigated by sewage within the first $10 \mathrm{~cm}$ was directly loose, and its resistance to penetration was less than $500 \mathrm{kPa}$. As a result, it did not affect the crop root growth. However, its resistance to penetration became obvious deeper in the soil layer. This is because it was $415 \mathrm{kPa}$ at $10 \mathrm{~cm}$ soil depth and $1473 \mathrm{kPa}$ at $45 \mathrm{~cm}$ soil depth. Study of compactness determines that there exists a trend for an unconsolidated topsoil layer, which was suitable for crop root growth, and increased the sensitivity of the crop to environmental change. Problems like soil compactness cannot be neglected in future agricultural production (Hernández et al., 2015).

Field capacity refers to the maximum amount of water maintained by the soil without including groundwater, and becomes the upper limit of available moisture for vegetation (Daniel, 1980; Qin, 2003). It is controlled by soil structure and soil texture, playing a vital role in controlling farmland water balance, irrigation and drainage, drought and moisture conservation (Shao et al., 2006). The field capacity of loam would be greater than that of sand under normal conditions (Jia \& Fan, 2007). When irrigated by sewage, its organic matter would go into the soil and increase the soil particle viscosity, thus increasing field capacity (Lan et al., 2010). Some similar research has confirmed that irrigation with eutrophic or untreated aquaculture wastewater did increase soil particle viscosity and enhanced field capacity (Wang \& Lin, 2003; He, 2012).

Impacts on soil chemical characteristics. Sewage irrigation can affect soil chemical properties through its effects on the soil $\mathrm{pH}$. This is one important factor which affects soil fertility (Bao, 2000). The formation and change of the soil acidity-alkalinity depends on the relative strength of the process of base substances leaching and accumulation (Dheri et al., 2007). The degree of acidity or alkalinity can be more conveniently expressed by the $\mathrm{pH}$ value (Huang, 2000). Since the soil has a certain buffer capacity, the $\mathrm{pH}$ value is relatively stable (Masto et al., 2009). Once the $\mathrm{pH}$ value varies drastically, the soil chemical properties will be changed accordingly, which affects directly the existing form, transformation and availability of soil nutrients (Ma \& Zhao, 2010). Soil pH changes are related to the types of irrigation water and soil category (Wan et al., 2015). He et al. (2012) showed that the soil $\mathrm{pH}$ value would decrease with the increase of irrigation times using wastewater from hoggery to irrigate a yellow clay. On the other hand, Xia et al. (2011) showed that the value of $\mathrm{pH}$ in soil increased if irrigated by effluents from paper-making factories making a moderately degraded saline-alkali soil. It was also found that there was no obvious effect on the soil $\mathrm{pH}$ of a vegetable field when sewage came from a livestock breeding enterprise (Zhang et al., 2011). The reason for the fluctuation of the $\mathrm{pH}$ value could be explained by the different degrees of ammoni- 
fication and nitrification of the soil organic matter, anaerobic organic matter decomposition, and release and enrichment of metal ions (Dheri et al., 2007; Rusan et al., 2007).

Organic matter is a significant component of the soil, and its content was usually be regarded as an important index for measuring soil fertility (Rattan et al., 2005). The accumulation of soil organic matter is not only closely related to natural environmental conditions, but it also depends on the input of organic matter by all means (Qin, 2003; Shao et al., 2006). Sewage irrigation could solve water shortage in the current agricultural production and also increases soil fertility. However, the amplitude of this increase showed great agrotype and spatial differences (Xue, 2012). Irrigation by eutrophic sewage showed that the soil organic matter content of sandy and loamy soils increased significantly. Values for the loamy soil increased from $2.73 \mathrm{~g} / \mathrm{kg}$ to $5.38 \mathrm{~g} / \mathrm{kg}$, (97.1\%), while values for the sandy soil increased from $0.85 \mathrm{~g} / \mathrm{kg}$ to $1.16 \mathrm{~g} /$ $\mathrm{kg}(36.5 \%)$ (Lan et al., 2010). Comparable differences in the content of soil organic matter also existed when considering increments of soil depth within the soil profile. Extremely significant increases in the content of soil organic matter were easily discovered within the first $20 \mathrm{~cm}$ of the topsoil, while the increase levels were significantly reduced with increases in soil depth $(\mathrm{Hu}, 2010)$. Furthermore, much effort in maintaining the global carbon balance have focused on the soil organic matter, which is considered of having a unique role in affecting the global warming worldwide. The cumulative effects of soil organic matter from sewage irrigation have become one of the inputs of soil organic carbon in farmland and participated in the global carbon circulation (Rattan et al., 2005; Zhang et al., 2008).

Nitrogen is an essential nutrient for crop growth, and its abundance and supply in the soil affect crop growth and development (Masto et al., 2009). A study of irrigation using aquaculture wastewater for a long time showed that nitrogen accumulation in soil increased significantly, and the nitrogen content in soil was significantly greater than that of the untreated farmland for more than 12 years (Zhang et al., 2011). There existed an obvious eutrophication when farmland was irrigated by sewage over a long period of time: alkali-hydrolysable nitrogen content increased significantly in each study soil layer, especially in the soil surface and its content could reach $8.26 \mathrm{mg} / \mathrm{kg}$, much higher than the average (Hu, 2010). In the meantime, nitrogen accumulation in the soil profile was significantly affected by nitrogen mobility and irrigation infiltration (Wiel-Shafran et al., 2006). The accumulation of $\mathrm{NO}_{2}{ }^{-}$and $\mathrm{NO}_{3}{ }^{-}$because of water eluviation caused groundwater pollution at shallow layers when polluted kratos water was adopted for irrigation (Zhang et al., 1996). Sewage irrigation had a lower impact on $\mathrm{NH}_{4}{ }^{+}$existing in deep soil and groundwater. However long-term sewage irrigated soil greatly influenced the $\mathrm{NO}_{3}{ }_{3}$ concentration, causing groundwater pollution at deep soil layers (Liu \& Lu, 2002).
Phosphorus is one of the three essential nutrients for plants. Not only it constitutes the components of many important compounds in plants, but also participates in various metabolic processes in plants by all means (Dalai, 1977; Redding et al., 2002; Marschner et al., 2007). The studies on farmland and forest lands found that the total phosphorus had significantly increased in the surface soil and most of it could be kept in the upper soil $(0-40 \mathrm{~cm})$ using long-term wastewater irrigation (Hu et al., 2010; Hu et al., 2012). Comparable concentrations were found in farmlands irrigated with swine wastewater: phosphorus accumulated in the plowing layer $(0-40 \mathrm{~cm})$ and increased with the advance of the time of irrigation ( $\mathrm{Yu}$, 2009). Reddling et al (2005) discovered that the soil available and total phosphorus contents were significantly higher than those from irrigation by piggery wastewater after anaerobic digestion, and phosphorus levels appeared to be a result of excessive accumulation in the top soil layer within $5 \mathrm{~cm}$.

Potassium is also a major nutrient in higher plants; together with nitrogen and phosphorus they are known as the three essential factors for plant nutrition. Available potassium refers to the potassium that is easily absorbed by the plant and becomes the main diagnostic index of soil fertility (Huang, 2000; Qin, 2003). In studies of $\mathrm{Hu}$ (2010) and Masto et al. (2009), the soil available potassium content increased greatly after sewage irrigation. This was mainly because a lot of nutrients were contained in the sewage, making available potassium enrichment possible in the soil surface. The content of total potassium in soil could also be improved for the application of molasses alcohol water in the sewage irrigation; it significantly increased total soil potassium content, improving soil fertility (Xu, 2007).

In general, heavy metals from sewage effluents could be adsorbed by soil particles. Because of this most heavy metal ions are concentrated in the soil, resulting in soil heavy metal pollution. It has become the most serious problem for human health (Liu et al., 2005; Mapanda \& Mangwayana, 2005; Wan et al., 2015). According to the bulletin of soil pollution published by the Chinese government in 2014, 39 out of 55 surveyed areas irrigated by sewage showed soil contamination by heavy metals. As much as $26.4 \%$ exceeded the maximum levels allowed of a total of 1378 soil points, and the main pollutants were cadmium, arsenic and polycyclic aromatic hydrocarbons. This metal distribution was homogeneous, but heavy metal spatial distribution has shown important differences (Liu et al., 2005; Hu et al., 2006; Khan et al., 2008). A broad distinction of vertical distribution of heavy metal pollution was drawn in the soil profile. Cao (2014) concluded that heavy metal elements mainly concentrated in the soil within the first $50 \mathrm{~cm}$ from the soil surface, and its vertical distribution varied with soil texture. Heavy metal content was related to the lithology structure in the soil vadose zone. Silt was not favorable for heavy metal accumulation and sandy soil took the second place. The main enrichment of heavy metals 
was reported in loamy soil (Wang \& Lin, 2003). The degree of heavy metal enrichment in soil is also closely related to the timing of wastewater irrigation and the concentration of heavy metal ions in sewage (Liu et al., 2005; Rattan et al., 2005). Wang et al (2008) found that long-term, excessive irrigation by sewage exceeded the standards and posed a threat to soils. This is, $\mathrm{Cu}, \mathrm{Pb}, \mathrm{Zn}, \mathrm{Cd}, \mathrm{As}, \mathrm{Hg}, \mathrm{Cr}$ and other harmful substances seriously exceeded the limits of soil capacity. Five toxic metals $(\mathrm{Cd}, \mathrm{Cr}, \mathrm{Cu}, \mathrm{Zn}, \mathrm{Pb})$ increased during sewage irrigation of farming areas in Beijing and Shenyang, and pollution with $\mathrm{Cd}, \mathrm{Cu}, \mathrm{Zn}$, and $\mathrm{Pb}$ was exacerbated in soils (Sun et al., 2006; Wang et al., 2006). Ultimately, these heavy metals are dangerous to human health through various food chains (Loska et al., 2004).

In addition to heavy metal pollution in soil, there exist various other degrees of organic pollutants in some sewage irrigation areas (Qadir et al., 2010). Organic pollutants, such as aromatic hydrocarbons, phenols, and organic chlorines are easily discovered in industrial wastewaters (Tian et al., 1993). A research by collecting seven different soil samples depths irrigated by wastewater in Taiyuan, Shanxi Province, determined that the constituent parts in sewage diversified and were extremely complicated; they were pollutants as plasticizer, such as phthalate esters, skatole, sterols, polycyclic aromatic hydrocarbons and so on. The most serious pollution of polycyclic aromatic hydrocarbons was found in soil. This substance has penetrated into the groundwater and also been detected in the nearby shallow groundwater (Du et al., 2010). A survey in the Shenyang and Fushun sewage irrigation area, the China's largest oil wastewater irrigated area, showed that the accumulation of toxic substances because of the petrochemical industrial sewage was serious. Among the toxic substances, the aromatic hydrocarbons represented an important proportion, and the carcinogens benzene and pyrene were severely exceeded (Zhang et al., 2003). The sensory indicators of rice produced in this region were extremely poor, with strong smell from oils and aromatic compounds (Fang, 2011).

Influence of soilmicroorganisms and enzyme activities. Soil microorganisms, as an important part for maintaining soil quality, participates in most of soil biological and biochemical activities, and are sensitive to reflect changes of soil quality health (Stenberg, 1999). The quantity, composition and activity of soil microbial population are a dynamic process; environmental changes and the number of microbial living cells constitute one of the most sensitive biological indicators (Li et al., 2005). Sewage irrigation would cause a change of microhabitat to some extent, having a great effect on soil microbial activities (Zhang et al., 2008). Soil bacteria, fungi and actinomycetes can be used to reflect the total amount of soil microorganisms that play a significant role on soil organic matter and inorganic material transformation (Aleem et al., 2003). The number of bacteria and actinomycetes in the soil showed a descending trend after long-term sewage irrigation, while the number of fungi increased slowly (Ge et al., 2009). Similar results were found in the Shenyang and Fushun sewage irrigation region: sewage irrigation changed the content of soil nutrients and multiring hydrocarbon, and then had a direct effect on microbial populations. Their total nitrogen showed very significantly positive correlations with bacteria, nitrogen-fixing bacteria, and phosphorus bacteria (Zhang et al., 2007; Zhang et al., 2008). In the meantime, the way of sewage irrigation application also affected the number of soil microorganisms (Heidarpour et al., 2007). A series of studies by Oron et al. (1999) displayed that soil surface humidity affected the total number of soil bacteria after sewage irrigation. When subsurface or underground drip irrigation was adopted, the total number of bacteria of subsurface drip irrigation was much higher than that of the underground. The most likely explanation would appear to be that soil played a role of secondary filter in the process of sewage infiltration, reducing the contact probability between sewage and aboveground vegetation parts (Oron et al., 1995; Oron et al., 1999).

Soil enzymes are active substances found in the soil, primarily coming from the soil microbes and plant root secretions and enzymes released by the decomposition of animal and plant residues (Burns \& Dick, 2002; Cao et al., 2003). Common enzymes mainly include oxidoreductases, hydrolytic enzymes, crack enzymes and transferation enzymes, all of which participate in and promote a large proportion of organic substance transformation and material circulation by soil ecological processes (Zhang et al., 2011). Some relevant research has produced evidence to suggest that irrigation by petroleum-processed wastewater could stimulate aerobic heterotrophic bacteria and fungi growth in the soil. The total petroleum hydrocarbon content in the soil showed a positive correlation with the soil dehydrogenase, catalase and polyphenol oxidase activities and a negative correlation with the soil urease activity ( $\mathrm{Li}$ et al., 2005). Other observations were found that soil enzyme activities were influenced by soil nutrients and multiring hydrocarbon pollution, after long-term irrigation by petroleumprocessing wastewater. The soil both organic carbon and total phosphorus content showed significant relationships with the dehydrogenase, polyphenol oxidase and urease activities. The content of multiring hydrocarbon was significantly positive correlated with the dehydrogenase, urease, and polyphenol oxidase activities (Zhang et al., 2007; Zhang et al., 2008). In Baoding, Hebei Province, a heavy industry city, it was determined that the soil urease and hydrogen peroxide enzyme activities increased with increases of soil $\mathrm{Pb}$ and $\mathrm{Cd}$ contents (Liu, 1996). Many studies have shown indirect influences caused by sewage irrigation such as soil secondary salinization in calcareous drab soil, which lead to constrain enzyme activities, causing a decline in soil environmental quality (Li, 2001). 
Implications for sewage irrigation development in the future

For the current development of sewage irrigation in China, governors must clearly realize that wastewater discharge itself is a guarantee to replace the water scarcity for grain production, and the huge population demands for food in China. On the other hand, the adverse effects brought by the sewage irrigation were removed completely. Therefore, any research and development involving sewage irrigation have to consider carefully the current situation in China. We suggest that four aspects should be taken into account for achieving a safe and efficient utilization of farmland wastewater irrigation in China.

Strict control of the pollution and supervising systems. At present, the first question for sewage irrigation in China is to solve the quality problem gradually. Starting from the sewage source, water quality monitoring should be much greater, and water quality of the wastewater entering the farmland should be strictly controlled (Engineering, 2000; Yang, 2000; Qadir et al., 2010). Contaminated water that seriously exceeds the threshold levels should be forbidden from discharging and utilization. Currently, governors always adopt an attitude towards removing responsibility of supervision and administration of sewage in the practice. Therefore, a management system of sewage irrigation should be established and implemented urgently. It has to explicit the appropriate responsibilities and embodiment at different stages of sewage discharge, disposal and irrigation (Zeng \& Zhu, 2004; Shi et al., 2014). For the companies and individuals in the wastewater irrigation area, awareness of environmental protection should be increased. For that illegal discharge, sewage behavior enterprises punishment needs to be much greater than their illegal profit. For the individual, the health risks from sewage irrigation should be extensively published, enhancing awareness of its effects on the environment and human health (Rattan et al., 2005; Wan et al., 2015).

Optimize the way of serwage irrigation, and avoid irrigation using a single-type-serwage for a long time. China has summarized some effective methods for sewage irrigation techniques through several decades of practicing. They include oxidation pond purifying wastewater treatment, and mixed irrigation between wastewater and clear water (Hong et al., 2011). However, the flooding irrigation mode is the most common adopted in the vast area of sewage irrigation. On the one hand, it wastes a lot of valuable sewage resources. At the same time, however, it causes serious soil pollution (Zhang et al., 2005). Thus, the current model of sewage irrigation should be changed and optimized, combining agricultural water-saving irrigation with sewage pretreatment, and developing an underground, aerated drip sewage irrigation. Considering the different crop growth stages, edible parts and contaminants in wastewater irrigation, sewage irrigation time and quantity need to be allocated reasonably, reducing the effect of sewage irrigation on crop growth and human health (Oron et al., 1995; Oron et al., 1999).
Control of serwage irrigation to local conditions and protecting groundrwater resources. Because of improper irrigation facilities and methods, unscientific irrigation systems and low management levels, field irrigation efficiency is low and percolation towards deep soil layers is serious (Liu \& Xu, 2002). Failing in making a proper sewage irrigation or irrigation by untreated sewage easily gives rise to infiltration of pollutants in the soil, endangering the security of drinking water and even forming inverse funnels of sewage, which pose a threat to deep groundwater. Once groundwater is contaminated, it will be difficult to recover, and the consequences will be severe. It seems reasonable to assume that it will not be suitable for sewage irrigation for some unadaptable wastewater irrigation areas such as those with strong soil permeability, high underground water level, aquifer outcrops and centralized drinking water sources, which will easily lead to groundwater pollution and be unfavorable to human health (Zhou, 2002; Qadir et al., 2010). Therefore, it is appropriate to adjust measures to local conditions for sewage irrigation, and reduce the environmental risks caused by sewage irrigation.

Adsorption and degradation of soil harmful substances by some plant and microbe characteristics of selective absorption. In the technical field of heavy metal contaminated soil repair, phytoremediation is highly favored for its advantages such as an excellent reinforced effect, low cost and high environmental benefits (Nie et al., 2016). At the same time, microorganisms could either fix heavy metal ions through their metabolic functions or convert toxic heavy metal ions into non-toxic or low-toxic conditions ( $\mathrm{Li}$ et al., 2015). Hyperaccumulators could be introduced to repair soils contaminated by sewage irrigation adopting their own strong absorption ability for some heavy metals and non-heavy metal toxicity. Furthermore, the function of microbial selective absorption was jointly utilized to establish the system of plant-microbial repairment, improving the efficiency of heavy metal pollution soil restoration (Rajkumar et al., 2010).

\section{CONCLUSIONS}

The biggest challenge that the Chinese government is now facing how to meet the soaring water demand of its expanding urban and industrial portions without decreasing its own agricultural needs. In consideration of world food security, sewage irrigation on a mass scale is indeed as an alternative way for water shortage in some areas of China. However, the effects of inappropriate sewage irrigation on soil physical (soil bulk density, soil resistance to penetration and field capacity), chemical ( $\mathrm{pH}$, soil organic matter, nitrogen, phosphorus, potassium, heavy metal and organic pollutants) and biological characteristics (soil microorganisms and enzyme activities) in farmlands should paid attention to its practical application. Some relevant, proper irrigation facilities and methods, scientific irrigation systems from agriculture and water resource 
departments, and high sewage management levels are worth applying. This is together with clear rewards and punishments from the government, popularized and applied in line with local conditions, promoting reclamation and high treatment efficiency of effluents in China.

\section{ACKNOWLEDGEMENTS}

This study was supported by the National Natural Science Foundation of China (51379085) and the School of Resource and Environment, Henan Institute of Science and Technology, China.

\section{REFERENCES}

Abaidoo, R.C., B. Keraita, P. Drechsel, P. Dissanayake \& A.S. Maxwell (2010). Soil and crop contamination through wastewater irrigation and options for risk reduction in developing countries. Springer, London.

Abu-Sharar, T.M., I.A. Hussein \& O.R. Al-Jayyousi (2010). The use of treated sewage for irrigation in Jordan: opportunities and constraints. Water Eं Environment Journal 17: 232-238.

Ahmed, H.A.-M., E.S. Gerald \& R.H. Hart (1987). Soil Bulk Density and Water Infiltration as Affected by Grazing Systems. Journal of Range Management 40: 307-309.

Aleem, A., J. Isar \& A. Malik (2003). Impact of long-term application of industrial wastewater on the emergence of resistance traits in Azotobacter chroococcum isolated from rhizospheric soil. Bioresource Technology 86: 7-13.

Angelakis, A.N., M.H.F.M.D., Monte, L. Bontoux \& T. Asano (1999). The status of wastewater reuse practice in the Mediterranean basin: need for guidelines. Water Research 33: 2201-2217.

Bao, S.D.(2000). Soil and Agricultural chemistry analysis, China Agriculture Press, Beijing.

Barber, R.G. (1994). Persistence of Loosened Horizons and Soybean Yield Increases in Bolivia. Soil Science Society of America Journal 58: 943-950.

Bouri, S., H. Abida \& H. Khanfir (2008). Impacts of wastewater irrigation in arid and semiarid regions: case of Sidi Abid region, Tunisia. Environmental Geology 53: 1421-1432.

Bouwer, H. (1994). Irrigation and global water outlook. Agricultural Water Management 25: 221-231.

Brown, L.R. (1995). Who will feed China? Wake-up call for a small planet.

Brown, L.R. \& B. Halweil (1998). China's water shortage could shake world food security. World Watch 11: 11-21.

Burns, R.G. \& R.P. Dick (2002). Enzymes in the Environment. Marcel Dekker, New York \& Basel.

Cao, H., H. Sun \& H. Yang (2003). A review: Soil enzyme activity and its indication for soil quality. Chinese Journal of Applied E Environmental Biology 9: 105-109.

Cao, S.P. (2004). Vertical distribution of heavy metal pollutant in soil profile of Tianjin. Contributions to Geology $\varepsilon^{\circ}$ Mineral Resources Research 19: 270-274.

Chen, P.H., K.C. Leung \& J.T. Wang (2000). Investigation of a ponding irrigation system to recycle agricultural wastewater. $E n-$ vironment International 26: 63-68.
Chen, Z.J. \& J.B. Zhou (2001). Application of Treated Wastewater on Agriculture in Israel. Agro-environmental Protection 20: 462464.

Dalai, R.C. (1977). Soil Organic Phosphorus. Advances in Agronomy 29: 83-117.

Daniel, H. (1980). Application of Soil Physics, Academic Press, Inck.

Dheri, G.S., M.S. Brar \& S.S. Malhi (2007). Heavy-Metal Concentration of Sewage-Contaminated Water and Its Impact on Underground Water, Soil, and Crop Plants in Alluvial Soils of Northwestern India. Communications in Soil Science E Plant Analysis 38: 1353-1370.

Du, B., J. Gong \& J.L. Li (2010). Study on organic pollution of soil and water environment by sewage irrigation in Taiyuan City. Yangtze River 41: 58-61.

Chinese Academy of Engineering (2000).Strategic Research on Sustainable Development of Water Resource in China. Engineering Science 2: 1-17.

Environmental Protection Agency (1992). Guidelines for Water Reuse. Washington DC.

Fang, Y.D. (2011). Research on the current situation, prevention and treatment of farmland wastewater irrigation in China. Journal of Agricultural Resources and Environment 5: 1-6.

Food and Agriculture Organization (1985). Water quality for irrigation, Irrigation and Drainage Paper. Rome.

Fatta-Kassinos, D., I.K. Kalavrouziotis, P.H. Koukoulakis \& M.I. Vasquez (2011). The risks associated with wastewater reuse and xenobiotics in the agroecological environment. Science of the Total Environment 409: 3555-3563.

Francks, P. (1979). The development of new techniques in agriculture: The case of the mechanization of irrigation in the Saga Plain area of Japan. World Development 7: 531-539.

Franzluebbers, A.J., S.F. Wright \& J.A. Stuedemann (2000). Soil aggregation and glomalin under pastures in the Southern Piedmont USA. Soil Science Society of America Journal 64: 1018-1026.

Ge, H.L., L. Chen, J.L. Zhang \& W.S. Huang (2009). Effect of Long-term Sewage Irrigation on Rhizosphere Soil Microbial Populations of Wheat. Water Saving Irrigation 5: 14-15.

Gu, S., A. Jenkins, S.J. Gao, Y. Lu, H. Li, Y. Li, R.C. Ferrier, M. Bailey, Y. Wang \& Y. Zhang (2017). Ensuring water resource security in China; the need for advances in evidence-based policy to support sustainable management. Environmental Science E Policy 75: 65-69.

Hass, U., U. Dünnbier \& G. Massmann (2012). Occurrence of psychoactive compounds and their metabolites in groundwater downgradient of a decommissioned sewage farm in Berlin (Germany). Environmental Science and Pollution Research 19: 20962106.

He, Y. (2012). The impact of pig farming waste water irrigation on soil physical and chemical properties, Chengdu University of Technology, Chengdu.

Heidarpour, M., B. Mostafazadeh-Fard, J.A. Koupai \& R. Malekian (2007). The effects of treated wastewater on soil chemical properties using subsurface and surface irrigation methods. Agricultural Water Management 90: 87-94.

Hernández, J.P., M.R. Befani, N.G. Boschetti, C.E. Quintero, E.L. Díaz, M. Lado \& A. Paz-González (2015). Impact of Soil Resistance to Penetration in the Irrigation Interval of Supplementary Irrigation Systems at the Humid Pampa, Argentina. Journal of Cardiac Failure 12: 87-88. 
Heukelekian, H. (1957). Utilization of Sewage for Crop Irrigation in Israel. Sewage Eं Industrial Wastes 29: 868-874.

Hong, H.J., M.W. Rui, T.S. Lin, P.F. Quan, N. Feng \& X.J. Zhou (2011). Oxidation Pond/Constructed Wetland for Treatment of Urban Polluted River Water. China Water E Wastewater 27: 35-38.

Hu, H.R., H.C. Ma \& Y.X. Wang (2010). Influence of Land Use Types to Nutrients, Organic Carbon and Organic Nitrogen of Soil. Soil E Water Conservation in China 11: 40-43.

Hu, H.R., H.L. Wang, B. Katie \& K. Mark (2012). Effect of long term effluent irrigation on content and movement of phosphorus in soil of forest land. Acta Pedologica Sinica 49: 560-566.

Hu, H.Y. (2010). Effect of sewage irrigation water on soil quality in farmland. Northwest A\&F University, Yangling.

Hu, K.L., F.R. Zhang, L. Hong, F. Huang \& B.G. Li (2006). Spatial Patterns of Soil Heavy Metals in Urban-Rural Transition Zone of Beijing. Pedosphere 16: 690-698.

Huang, C.Y. (2000). Soil Science. China Agriculture Press, Beijing.

Jia, F. \& G.S. Fan (2007). Study on the relationship between soil texture and field water holding rate. Soil and Water Conservation Science and Technology in Shanxi 3:17-19.

Jin, L.S. \& W. Young (2001). Water Use in Agriculture in China: Importance, Challenges, and Implications for Policy. Water Policy 3: $215-228$

Karr, J.R. (1991). Biological Integrity: A Long-Neglected Aspect of Water Resource Management. Ecological Applications 1: 66-84.

Jueschke, E., B. Marschner, J. Tarchitzky \& Y. Chen (2008). Effects of treated wastewater irrigation on the dissolved and soil organic carbon in Israeli soils. Water Science E Technology A Journal of the International Association on Water Pollution Research 57: 727-733.

Keesstra, S.D., V. Geissen, K. Mosse, S. Piiranen, E. Scudiero, M. Leistra \& L. van Schaik (2012). Soil as a filter for groundwater quality. Current Opinion in Environmental Sustainability 4: 507516.

Khan, S., Q. Cao, Y.M. Zheng, Y.Z. Huang \& Y.G. Zhu (2008). Health risks of heavy metals in contaminated soils and food crops irrigated with wastewaRter in Beijing, China. Environmental Pollution 152: 686-692.

Killham, K. (1994). Soil Ecology. Cambrige Unisity Press, Cambrige.

Lan, M.J., M.S. Li, G.J. Zhao \& L. Rui (2000). Effects of Eutrophic Sewage Irrigation on Soil-holding Capacity. Journal of Shihezi University 28: 497-500.

Li, B., C. Yang \& P. Lin (2000). Ecology. Higher Education Press, Beijing.

Li, F., M. Benhur \& R. Keren (2003). Effect of marginal water irrigation on soil salinity, sodicity and crop yield. Transactions of the Chinese Society of Agricultural Engineering 19: 63-66.

Li, F., G. Huang, Y. Ding \& C. Peng (2006). Effects of soil alkalinity, gypsum application, and filtration disposal on hydraulic conductivity under irrigation with domestic effluent water. Transactions of the Chinese Society of Agricultural Engineering 22: 48-52.

Li, H., G. Chen, T. Yang \& C.G. Zhang (2005). Impacts of petroleum-containing wastewater irrigation on microbial population and enzyme activities in paddy soil of Shenfu irrigation area. Chinese Journal of Applied Ecology 16: 1355-1359.

Li, L.Q. (2001). Study on properties of physies and chemistry of cinnamon soil with wastewater irrigation. Journal of Shanxi Agricultural University 21: 73-75.

Li, S.Z. \& J.F. Luo (1995). Sewage irrigation and environmental quality control in China. China Meteorological Press, Bejing.
Li, Y.S., C.L. Feng, X.F.Wu \& R. Shi (2015). A review on the functions of microorganisms in the phytoremediation of heavy metalcontaminated soils. Acta Ecologica Sinica 35: 6881-6890.

Liu, L. \& G.H. Lu (2002). Nitrogen wastewater irrigation study and its contamination risk analysis. Advances in Water Science 13: 313-320.

Liu, R.T. \& J.Z. Xu (2002). Sewage water irrigation problems and solutions in China, China Water Resources 10: 123-125.

Liu, S.Q. (1996). Relationship between soil $\mathrm{Pb}$ and $\mathrm{Cd}$ pollution and enzyme activities in wastewater irrigated area of baoding city. Acta Pedologica Sinica 33: 175-182.

Liu, W. H., J.Z. Zhao, Z.Y. Ouyang, L. Söderlund \& G.H. Liu (2005). Impacts of sewage irrigation on heavy metal distribution and contamination in Beijing, China. Environment International 31: 805-812.

Loska, K., D. Wiechuła \& I. Korus (2004). Metal contamination of farming soils affected by industry. Environment International 30: 159-165.

Lottermoser, B.G. (2012). Effect of long-term irrigation with sewage effluent on the metal content of soils, Berlin, Germany. Environmental Geochemistry \& Health 34: 67-76.

Ma, Q. \& G.X. Zhao (2010). Effects of different land use types on soil nutrients in intensive agricultural region. Journal of Natural Resources 25: 1834-1844.

Mapanda, F. \& E.N. Mangwayana (2005).The Effects of long-term irrigation using water on heavy metal contents of soils under vegetables. Agriculture Ecosystems Eซ Environment 107: 151-165.

Marschner, P., Z. Solaiman \& Z. Rengel (2007). Brassica genotypes differ in growth, phosphorus uptake and rhizosphere properties under P-limiting conditions. Soil Biology E Biochemistry 39: 87-98.

Masto, R.E., P.K. Chhonkar, D. Singh \& A.K. Patra (2009). Changes in soil quality indicators under long-term sewage irrigation in a sub-tropical environment. Environmental Geology 56: 1237-1243.

Meng, W.Q. Z.W. Wang, B.B. Hu, Z.L. Wang, H.Y. Li \& R.C. Goodman (2016). Heavy metals in soil and plants after longterm sewage irrigation at Tianjin China: A case study assessment. Agricultural Water Management 171: 153-161.

Molles, M. (2008). Ecology. Concepts and Application. McGrawHill Education, London.

Morishita, T. (1988). Environmental hazards of sewage and industrial effluents on irrigated farmlands in Japan. Elsevier Ltd, London.

Mullins, G.L., D.W. Reeves, C.H. Burmester \& H.H. Bryant (1994). In-row subsoiling and potassium placement effects on root growth and potassium content of cotton. Agronomy Journal 86: $136-139$.

Neves, C.S.V.J., C. Feller, M.F. Guimarães, C.C. Medina, J.T. Filho $\&$ M. Fortier (2003). Soil bulk density and porosity of homogeneous morphological units identified by the Cropping Profile Method in clayey Oxisols in Brazil. Soil E Tillage Research 71: 109-119.

Nie, Y.P., X.W. Wang, J.R. Wan, Y.Y. Yin, W.P. Xu \& W.T. Yang (2016). Research progress on heavy metal (Pb, Zn, Cd, Cu) hyperaccumulating plants and strengthening measures of phytoremediation. Ecological Science 35: 174-182.

Oron, G., C. Campos, L. Gillerman \& M. Salgot (1999). Wastewater treatment, renovation and reuse for agricultural irrigation in small communities. Agricultural Water Management 38: 223-234.

Oron, M.G., M. Goemans, Y. Manor \& J. Feyen (1995). Poliovirus distribution in the soil-plant system under reuse of secondary wastewater. Water Research: 29: 1069-1078. 
Pedrero, F., I. Kalavrouziotis, J.J. Alarcón, P. Koukoulakis \& T. Asano (2010). Use of treated municipal wastewater in irrigated agriculture - review of some practices in Spain and Greece. Agricultural Water Management 97: 1233-1241.

Pescod, M.B. (1992). Wastewater treatment and use in agriculture. FAO, Rome.

Piao, S., P. Ciais, Y. Huang, Z. Shen, S. Peng, J. Li, L. Zhou, H. Liu, Y. Ma \& Y. Ding (2010). The impacts of climate change on water resources and agriculture in China. Nature 467: 43-47.

Qadir, M., B.R. Sharma, A. Bruggeman, R. Choukr-Allah \& F. Karajeh (2007). Non-conventional water resources and opportunities for water augmentation to achieve food security in water scarce countries. Agricultural Water Management 87: 2-22.

Qadir, M., D. Wichelns, L. Raschidsally, P.G. Mccornick, P. Drechsel, A. Bahri, P.S. Minhas, D. Molden \& C. De Fraiture (2010). The challenges of wastewater irrigation in developing countries. Agricultural Water Management: 97: 561-568.

Qin, Y.D. (2003). Soil Physics. Higher Education Press, Beijing.

Rajkumar, M., N. Ae, M. Prasad \& H. Freitas (2010). Potential of siderophore-producing bacteria for improving heavy metal phytoextraction. Trends in Biotechnology 28: 142-149.

Rattan, R.K., S.P. Datta, P.K. Chhonkar, K. Suribabu \& A.K. Singh (2005). Long-term impact of irrigation with sewage effluents on heavy metal content in soils, crops and groundwater--a case study. Agriculture Ecosystems E Environment 109: 310-322.

Redding, M.R., A. Biggs, T. Gardner \& D. Duperouzel (2002). An overview of land application of pig effluent-P using soil $\mathrm{P}$ chemistry and mass balance calculations. Soil Research 40: 81-91.

Rusan, M.J.M., S. Hinnawi \& L. Rousan (2007). Long term effect of wastewater irrigation of forage crops on soil and plant quality parameters. Desalination 215: 143-152.

Sabol, G.V., H. Bouwer \& P.J. Wierenga (1987). Irrigation Effects in Arizona and New Mexico. Journal of Irrigation $\mathcal{E}^{\circ}$ Drainage Engineering 113: 30-48.

Shao, M.A., Q.J. Wang \& M.B. Huang (2006). Soil physics. Higher Education Press, Beijing.

Shi, R.G., D.R. Wang,Y.J.Zhao, F.Z. Liu,H.Y.Gao, Y.M. Cai \&Y.Shen (2006). Water quality control indexes of reclaimed municipal wastewater for farmland irrigation. China Water E Wastewater 22: 100-104.

Shi, R.G., Q.X. Zhou, F.Z. Liu, Y.J. Zhao, X.Q. Zheng, Y.M. Cai \& D.R. Wang (2008). Water quality standard and irrigation regulation of reclaimed water from municipal wastewater for farmland irrigation. Journal of Agro-Environment Science 27: 839-843.

Shi, Y., Q. XB \& Q. Gao (2014). Advance in Sewage Irrigation Safety Research and Proposal Countermeasure in China. Water Saving Irrigation 3: 37-44.

Siebe, C. \& W.R. Fischer (1996). Effect of long-term irrigation with untreated sewage effluents on soil properties and heavy metal adsorption of leptosols and vertisols in Central Mexico. Journal of Plant Nutrition E Soil Science 159: 357-364.

Singh, P.K., P.B. Deshbhratar \& D.S. Ramteke (2012). Effects of sewage wastewater irrigation on soil properties, crop yield and environment. Agricultural Water Management 103: 100-104.

Stenberg, B. (1999). Monitoring soil quality of arable land: microbiological indicators. Acta Agriculturae Scandinavica 49: 1-24.

Sun, L.N., Y.H. Zhang, T.H. Sun, Z.Q. Gong, X. Lin \& H.B. Li (2006). Temporal-spatial distribution and variability of cadmium contamination in soils in Shenyang Zhangshi irrigation area, China. Journal of Environmental Sciences 18: 1241-1246.
Tang, C., J. Chen, S. Shindo, Y. Sakura, W. Zhang \& Y. Shen (2004). Assessment of groundwater contamination by nitrates associated with wastewater irrigation: A case study in Shijiazhuang region, China. Hydrological Processes 18: 2303-2312.

Thomas, A. (2008). Agricultural irrigation demand under present and future climate scenarios in China. Global \& Planetary Change 60: 306-326.

Tian, J.Y., H.K. Zhang, J.M. Bao \& F.H. Wang (1993). Organic Compound Pollution in Xiaoqing River and its Influence on Ecosystem of Sewage-Irrigatcd Area. Chinese Journal of Ecology 12: 14-22.

Vörösmarty, C.J., P. Green, J. Salisbury \& R.B. Lammers (2000). Global water resources: vulnerability from climate change and population growth. Science 289: 284.

Wallach, R., O. Ben-Arie \& E.R. Graber (2005). Soil water repellency induced by long-term irrigation with treated sewage effluent. Journal of Environmental Quality 34: 1910-1920.

Wan, L., M.R. Zhang, S. Lu \& K. Hu (2015). Study progress on effect of polluted water irrigation on soil and problem analysis. Ecology and Environmental Sciences 24: 906-910.

Wang, G.L. \& W.J. Lin (2003). Contamination of soil from sewage irrigation and its remediation. Journal of Agro-environmental Science 22: 163-166.

Wang, G.L., C.Z. Liu, Z.Y. Lu \& A.P. Wang (2006). Influences of sewage irrigation on the field soil quality in Baiyin City. Journal of Gansu Agricultural University 41: 79-82.

Wang, Y., L.X. Sheng, K. Li \& H.Y. Sun (2008). Analysis of present situation of water resources and countermeasures for sustainable development in China. Journal of Water Resources E Water Engineering 19: 10-14.

Wang, Y.Q. S.Y. Li \& X.D. Cai (2010). Advance of Research on Sewage Irrigation in Farmland in China. Tianjin Agricultural Sciences 16: 77-80.

Weber, S., S. Khan \& J. Hollender (2006). Human risk assessment of organic contaminants in reclaimed wastewater used for irrigation. Desalination 187: 53-64.

Wescott, D.W. (1997). Quality control of wastewater for irrigated crop production. FAO, Rome.

Wiel-Shafran, A., Z. Ronen, N. Weisbrod, E. Adar \& A. Gross (2006). Potential changes in soil properties following irrigation with surfactant-rich greywater. Ecological Engineering 26: 348354.

Xia, J.B., W.J. Xie, J.K. Sun, J.T. Liu, Q. Liu \& Z.H. Lu (2011). Effects of paper-making wastewater irrigation on reed growth and its soil improvement. Journal of Soil E Water Conservation 25: 110-109.

Xia, L.J. \& H.K. Wang (2001). Soil pollution and countermeasures. Huazhong University of Science Press, Wuhan.

Xu, G. (2007). Effect of sewage irrigation with molasses alcohol waterwater on soil quality. Guangxi University, Nanning.

Xue, Z.J. (2012). Assessment of soil quality and pollution risk in main sewage-irrigated area of Hebei province. Agricultural University of Hebei Province, Baoding.

Yang, J.F. (2000). The Problem on Agricultural Sewage Irrigation and Countermeasures. Water Resources Protection 2: 4-8.

$\mathrm{Yu}$, D. (2009). Study on characteristics of soil phosphorus transport and transformation in the farmland with swine wastewater irrigation. Chinese Academy of Agricultural Sciences, Beijing. 
Zeng, D.F. \& W.B. Zhu (2004). Discussion on problems of sewage irrigation and countermeasures in China. Agricultural Research in the Arid Areas 22: 221-224.

Zeng, X.B., L.F. Li \& X.R. Mei (2007). Heavy metal content in soils of vegetable-growing lands in China and source analysis. Scientia Agricultura Sinica 40: 2507-2517.

Zhang, D.G., Y.L. Yi \& X.L. Zheng (2003). Effect of Petroleum Groups on Soil and Rice in the Shen-Fu Irrigation Region. Chinese Journal of Soil Science 34: 333-336.

Zhang, J., H.W. Zhang, Z.C. Su, X.Y. Li \& C.G. Zhang (2007). The Effect of Long-term Organic Wastewater Irrigation on the soil nitrogen-fixing bacteria population. Journal of Agro-Environment Science 26: 662-666.

Zhang, J., H.W. Zhang, Q. Zhang \& C.G. Zhang (2008). Impact of long-time irrigation of petroleum wastewater on glebe microbial biomass and soil enzyme activities in Northeast China. Chinese Journal of Eco-Agriculture 16: 67-70.

Zhang, J.Y. \& G.Q.Wang (2007). The impacts of climate change on hydrology and water resources. Science Press, Beijing.

Zhang, L.H. (2014). China's early exploration in sewage irrigation and pollution prevention (1949-1972). Researches Economic History 2: 153-165.

Zhang, L.J., X.Q. Huang, F. Wu \& H.Q. Wu (2005). Study of Agricultural Tridimension Pollution on Irrigation Farmland and Its Control Tactics. Journal of Irrigation E Drainage 24: 1-5.

Zhang, M.K., L.J. Liu \& C. Huang (2011). Effects of Long-term Irrigation of Livestock Farm Wastewater on Soil Quality and Vegetable Quality in Vegetable Soils. Journal of Soil E' Water Conservation 25: 87-91.

Zhang, W.L., Z.X. Tian, N. Zhang \&X.Q.Li (1996). Nitrate pollution of groundwater in northern China. Agriculture Ecosystems E Environment 59: 223-231.

Zhang, Y.L., J.L. Dai \& R.Q. Wangab (2008). Effects of long-term sewage irrigation on agricultural soil microbial structural and functional characterizations in Shandong, China. European Journal of Soil Biology 44: 84-91.

Zhou, T. (2002). Decision and technology of wastewater reuse. Chemical Industry Press, Beijing. 